\title{
Local and Systemic Induced Resistance to the Root-Knot Nematode in Tomato by DL- $\beta$-Amino-n-Butyric Acid
}

\author{
Yuji Oka, Yigal Cohen, and Yitzhak Spiegel
}

First and third authors: Department of Nematology, Agricultural Research Organization (ARO), The Volcani Center, Bet Dagan 50250, Israel; second author: Faculty of Life Sciences, Bar-Ilan University, Ramat-Gan 52900, Israel.

Accepted for publication 27 July 1999.

\begin{abstract}
Oka, Y., Cohen, Y., and Spiegel, Y. 1999. Local and systemic induced resistance to the root-knot nematode in tomato by DL- $\beta$-amino- $n$-butyric acid. Phytopathology 89:1138-1143.

Chemical inducers of pathogenesis-related proteins and plant resistance were applied to tomato plants, with the aim of inducing resistance to the root-knot nematode Meloidogyne javanica. Relative to control plants, foliar spray and soil-drenching with DL- $\beta$-amino- $n$-butyric acid (BABA) reduced root-galling 7 days after inoculation, as well as the number of eggs 30 days after inoculation. Other chemicals $(\alpha$ - and $\gamma$-amino- $n$-butyric

totoxic to tomato plants or did not improve control of root-knot nematodes. Fewer second-stage juveniles invaded BABA-treated tomato roots, and rootgalling indices were lower than in control tomato plants. Resistance phenomena in seedlings lasted at least 5 days after spraying with BABA. Nematodes invading the roots of BABA-treated seedlings induced small, vacuolate giant cells. Postinfection treatment of tomato plants with $\mathrm{BABA}$ inhibited nematode development. It is speculated that after BABA application tomato roots become less attractive to root-knot nematodes, physically harder to invade, or some substance(s) inhibiting nematode or nematode feeding-site development is produced in roots.
\end{abstract} acid, jasmonic acid, methyl jasmonate, and salicylic acid) were either phy-
Acquired or induced resistance of plants to pathogens can be achieved by inoculating a plant with incompatible or weak pathogens (2) or by applying chemical inducers, such as benzothiadiazole (10), 2,6-dichloroisonicotinic acid (33), or salicylic acid (SA) (15). In contrast to genetic resistance, induced resistance protects plants from a broad spectrum of pathogens and works systemically in many instances. Systemic resistance induced by local infection by a pathogen that induces necrotic lesions is termed systemic acquired resistance (SAR). Such acquired and induced resistance has been reported in many plant species challenged with different pathogens and chemicals, and the mechanisms governing it are being elucidated $(27,30)$. In many cases, SAR involves expression of a set of genes, including those encoding pathogenesisrelated (PR) proteins and enzymes $(27,30)$. SA is thought to be essential for establishment of SAR in plants $(16,27)$; exogenous $\mathrm{SA}$ induces resistance in many plant species.

Treatment with DL- $\beta$-amino- $n$-butyric acid (BABA) induces plant resistance to fungal pathogens as well, and PR proteins accumulate in tomato plants treated with this amino acid $(3,4,7,13,31)$. BABA is a nonprotein amino acid that, until recently (9), had not been reported in nature (26). Plant molecules thought to be plantdefense signals, such as ethylene, systemin, jasmonic acid (JA), and methyl jasmonate (MeJA), also have been reported to induce local and systemic resistance in plants to several pathogens (34).

Several amino acids, such as DL-methionine, DL-aminobutyric acid, and DL- and L-proline, have been used in soil-drenches as antimetabolites for nematodes and have reduced nematode damage $(8,22,32)$. SAR to Meloidogyne hapla was obtained in tomato (Lycopersicon esculentum Mill.) and pyrethrum (Chrysanthemum cinerariaefolium) plants through prior inoculation with two other hostincompatible, root-knot nematode species, $M$. incognita and $M$. javanica $(17,18)$.

Corresponding author: Y. Oka; E-mail address: okayuji@ netvision.net.il

Publication no. P-1999-1004-01R

(C) 1999 The American Phytopathological Society
In our previous work, no indication of acidic PR proteins was found in tomato plants after invasion by $M$. javanica (20). In contrast, PR proteins, including $\beta$-1,3-glucanase and $\beta$-glycosidase, were induced in potato (Solanum tuberosum) plants infected with potato cyst nematodes, regardless of plant resistance or susceptibility to the nematodes $(11,23,24)$. In our current investigation, the possibility of inducing resistance to $M$. javanica in tomato plants by chemical inducers of plant resistance was investigated.

\section{MATERIALS AND METHODS}

Nematode and plant material. Second-stage juveniles (J2) of $M$. javanica were hatched from eggs recovered from tomato (cv. Faculta 68 ) roots with sodium hypochlorite (12). Nematode development within roots was monitored under a stereomicroscope after root staining with acid fuchsin (1). Tomato plants (cvs. Faculta 68 and M-82) susceptible to $M$. javanica were used for the experiments.

Effect of chemicals on plant and nematode infection. Tomato seedlings (cv. Faculta 68) with four compound leaves were planted in sandy soil $(0.3 \%$ organic matter, $\mathrm{pH} 7.8)$ in $130-\mathrm{cm}^{3}$ plastic pots and sprayed $(\approx 1 \mathrm{ml}$ per plant) or soil-drenched $(10 \mathrm{ml}$ per plant) with $20 \mathrm{mM}$ DL- $\alpha$-amino- $n$-butyric acid (AABA), BABA, or $\gamma$-amino$n$-butyric acid (GABA); $2.5 \mathrm{mM}$ JA, $2.5 \mathrm{mM}$ MeJA, or $10 \mathrm{mM} \mathrm{SA}$; or water as a control. All chemicals were purchased from Sigma Chemical Co. (St. Louis, MO), except MeJA, which was provided by Firmenich (Geneva). One day after treatment, seedlings were inoculated with $\approx 1,000 \mathrm{~J} 2$ in $1 \mathrm{ml}$ of water, kept at $27 \pm 1^{\circ} \mathrm{C}$ for 14-h days, and fertilized weekly with a 20-20-20 (N-P-K) fertilizer solution. Some plants were harvested 7 days after inoculation, and root-gall indices (GI: 0 to 5) (19) were recorded. At 30 days after inoculation ( 23 days after first harvest), the rest of the plants were harvested, and shoot and root fresh weights, GI, and number of nematode eggs were recorded. Each treatment was performed in five replicates. Data were subjected to analysis of variance, and means were separated by least significant difference test $(P=0.05)$. To test the direct effect of chemicals on $\mathrm{J} 2, \approx 60 \mathrm{~J} 2$ were incubated in $500 \mu \mathrm{l}$ of chemical solution, at concentrations used in the ex- 
periment, in a 24-well plate (Nunc, Roskilde, Denmark) for 3 days at $27^{\circ} \mathrm{C}$ or in water as a control. After incubation, the percentage of immobilized nematodes was recorded. Each treatment was performed in five replicates. The experiment was conducted once.

Effect of BABA concentration. Tomato seedlings (2-week-old cv. M-82) planted in $25-\mathrm{cm}^{3}$ pots filled with sandy soil were sprayed with $(\approx 0.5 \mathrm{ml}$ per plant) $\mathrm{BABA}$ at concentrations of $5,10,20$, or $40 \mathrm{mM}$ or soil-drenched with $2 \mathrm{ml}$ of BABA at concentrations of $1.0,2.5$, or $5.0 \mathrm{mM}$. Seedlings were inoculated with $\approx 80 \mathrm{~J} 22$ days after application. At 5 days after inoculation, GI and number of J2 in roots were recorded. The experiment was performed in eight replicates and conducted twice.

Pretreatment with BABA. Tomato seedlings (2-week-old cv. M-82) planted in sandy soil in $25-\mathrm{cm}^{3}$ polystyrene cups were sprayed with $(\approx 0.5 \mathrm{ml}$ per plant) $20 \mathrm{mM} \mathrm{BABA}$ and inoculated with $\approx 100$ $\mathrm{J} 2$ immediately or 1,3 , or 5 days after spraying. GI and number of $\mathrm{J} 2$ in roots were recorded at 4 days after inoculation. Untreated plants served as a control. Each treatment was performed in eight replicates and conducted twice.

TABLE 1. Effect of chemical treatments on infection of tomato plants by Meloidogyne javanica

\begin{tabular}{|c|c|c|c|c|c|}
\hline \multirow[b]{2}{*}{ Treatment $^{\mathrm{z}}$} & \multirow{2}{*}{$\begin{array}{l}\text { Shoot } \\
\text { fr. wt. (g) }\end{array}$} & \multirow{2}{*}{$\begin{array}{l}\text { Root } \\
\text { fr. wt. (g) }\end{array}$} & \multicolumn{2}{|c|}{ Root galling index } & \multirow{2}{*}{$\begin{array}{c}\text { No. of } \\
\text { eggs }(\times 100)\end{array}$} \\
\hline & & & 7 days & 30 days & \\
\hline \multicolumn{6}{|l|}{ Spray } \\
\hline AABA & $4.4 \mathrm{~d}$ & $3.3 \mathrm{ab}$ & $1.1 \mathrm{bc}$ & $3.6 \mathrm{a}$ & $898 \mathrm{~b}-\mathrm{d}$ \\
\hline BABA & $8.2 \mathrm{a}-\mathrm{c}$ & $3.4 \mathrm{ab}$ & $0.8 \mathrm{c}$ & $3.9 \mathrm{a}$ & $464 \mathrm{~d}$ \\
\hline GABA & $8.8 \mathrm{a}-\mathrm{c}$ & $3.7 \mathrm{ab}$ & $3.7 \mathrm{a}$ & $3.7 \mathrm{a}$ & $1,316 \mathrm{ab}$ \\
\hline SA & $9.0 \mathrm{a}-\mathrm{c}$ & $3.7 \mathrm{ab}$ & $3.1 \mathrm{a}$ & $3.8 \mathrm{a}$ & $1,192 \mathrm{ab}$ \\
\hline JA & $8.6 \mathrm{a}-\mathrm{c}$ & $3.9 \mathrm{ab}$ & $3.5 \mathrm{a}$ & $3.7 \mathrm{a}$ & $1,074 \mathrm{a}-\mathrm{c}$ \\
\hline MeJA & $9.6 \mathrm{ab}$ & $4.1 \mathrm{ab}$ & $3.2 \mathrm{a}$ & $3.8 \mathrm{a}$ & $1,132 \mathrm{a}-\mathrm{c}$ \\
\hline \multicolumn{6}{|l|}{ Drench } \\
\hline AABA & $10.2 \mathrm{a}$ & $3.8 \mathrm{ab}$ & $3.2 \mathrm{a}$ & $3.2 \mathrm{a}$ & $1,292 \mathrm{ab}$ \\
\hline BABA & $8.3 \mathrm{a}-\mathrm{c}$ & $3.1 \mathrm{ab}$ & $2.5 \mathrm{ab}$ & $3.5 \mathrm{a}$ & $418 \mathrm{~d}$ \\
\hline GABA & $8.9 \mathrm{a}-\mathrm{c}$ & $4.7 \mathrm{a}$ & $3.6 \mathrm{a}$ & $3.4 \mathrm{a}$ & $1,584 \mathrm{a}$ \\
\hline SA & $10.3 \mathrm{a}$ & $3.9 \mathrm{ab}$ & $3.2 \mathrm{a}$ & $3.8 \mathrm{a}$ & $852 b-d$ \\
\hline JA & $7.6 \mathrm{bc}$ & $3.0 \mathrm{ab}$ & $3.2 \mathrm{a}$ & $3.8 \mathrm{a}$ & $842 b-d$ \\
\hline MeJA & $6.9 \mathrm{~cd}$ & $2.5 \mathrm{bc}$ & $2.3 \mathrm{ab}$ & $3.7 \mathrm{a}$ & $544 \mathrm{~cd}$ \\
\hline Control & $9.2 \mathrm{a}-\mathrm{c}$ & $3.4 \mathrm{ab}$ & $3.4 \mathrm{a}$ & $3.9 \mathrm{a}$ & $1,156 \mathrm{a}-\mathrm{c}$ \\
\hline
\end{tabular}

${ }^{\mathrm{z}}$ Tomato seedlings with four compound leaves were sprayed or soil-drenched with specified solutions. Each plant was inoculated with 1,000 juveniles of M. javanica 1 day after treatment. Data are means of five replicates. Values followed by the same letter in a column do not differ significantly, according to the least significant difference test $(P=0.05)$. AABA $=\mathrm{DL}-\alpha-$ amino- $n$-butyric acid $(20 \mathrm{mM})$; BABA $=$ DL- $\beta$-amino- $n$-butyric acid $(20 \mathrm{mM})$; GABA $=\gamma$-amino- $n$-butyric acid $(20 \mathrm{mM}) ; \mathrm{SA}=$ salicylic acid $(10 \mathrm{mM}) ; \mathrm{JA}=$ jasmonic acid $(2.5 \mathrm{mM})$; MeJA = methyl jasmonate $(2.5 \mathrm{mM})$.
Postinfection spray. Tomato seedlings (4-week-old cv. M-82) planted in sandy soil in $125-\mathrm{cm}^{3}$ pots were inoculated with $\approx 300 \mathrm{~J} 2$. At 5 days after inoculation, seedlings were gently removed from the soil, their roots were washed in water, and they were planted again in noninfested soil. One day after planting, half the plants were sprayed $(\approx 1 \mathrm{ml}$ per plant) with $20 \mathrm{mM}$ BABA. Nematode development within roots was observed 3 weeks later, after staining with acid fuchsin. Each treatment was performed in five replicates and conducted twice.

Reiterative application. Tomato plants (cv. M-82, 4 weeks old) planted in $125-\mathrm{cm}^{3}$ pots filled with sandy soil were sprayed $(\approx 1 \mathrm{ml}$ per plant) with $20 \mathrm{mM}$ BABA or soil-drenched with $8 \mathrm{ml}$ of $5 \mathrm{mM}$ BABA one, two, or three times at 10-day intervals. Plants were inoculated with $\approx 400 \mathrm{~J} 22$ days after the first application. Shoot and root fresh weights, GI, and number of eggs were recorded at 40 days after inoculation. The experiment was performed in seven replicates and conducted twice.

Tissue-processing for light and scanning electron microscopy. Tomato seedlings (3-week-old cv. M-82) were sprayed with $(\approx 1 \mathrm{ml}$ per plant) $20 \mathrm{mM}$ BABA and inoculated with $\approx 100 \mathrm{~J} 22$ days after spraying. Root segments ( $2 \mathrm{~mm}$ long) were cut from J2-infected roots of untreated or BABA-treated plants and fixed in $2.5 \%$ glutaraldehyde in $0.1 \mathrm{M}$ phosphate buffer ( $\mathrm{pH} 7.2$ ) overnight at $4^{\circ} \mathrm{C}$. For light microscopy, specimens were postfixed in $1 \%$ osmium tetroxide in phosphate buffer for $1 \mathrm{~h}$ at room temperature, washed three times with the same buffer, and dehydrated in a dilution series of ethanol. Specimens were infiltrated with increasing percentages of epoxy resin in acetone (50\% for $8 \mathrm{~h} ; 70 \%$ for $5 \mathrm{~h}$; and $100 \%$

TABLE 2. Effect of inoculation time on Meloidogyne javanica infection of tomato seedlings sprayed with DL- $\beta$-amino- $n$-butyric acid (BABA)

\begin{tabular}{lcccc}
\hline & \multicolumn{4}{c}{ Days after BABA treatment } \\
\cline { 2 - 5 } Treatment $^{2}$ & 0 & 1 & 3 & 5 \\
\hline No. of J2 & & & & \\
Control & 52.6 & 60.4 & 59.5 & 57.3 \\
BABA & 13.0 & 13.3 & 12.8 & 19.8 \\
GI & & & & \\
Control & 4.0 & 4.2 & 3.7 & 4.2 \\
BABA & 2.0 & 0.5 & 0.2 & 2.5 \\
\hline
\end{tabular}

${ }^{\mathrm{z}}$ Tomato seedlings were sprayed with $20 \mathrm{mM}$ BABA and inoculated with $\approx 100$ second-stage juveniles (J2) of $M$. javanica immediately or 1,3 , or 5 days after spraying. Four days after inoculation, the number of $\mathrm{J} 2$ in the roots and the root galling indices (GI) were recorded. Values are means of eight replicates. At all inoculation dates, J2 and GI values for BABA-treated seedlings were significantly lower than those for the control, according to Student's $t$ test $(P<0.05)$.
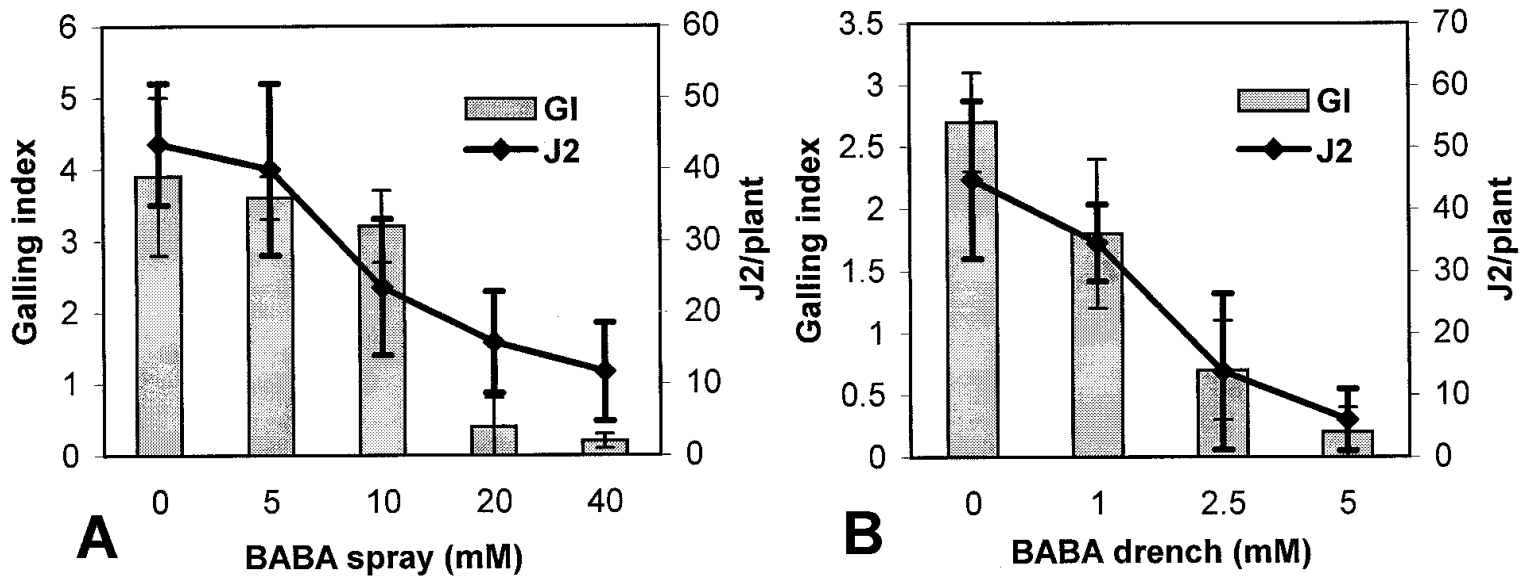

Fig. 1. Effect of DL- $\beta$-amino- $n$-butyric acid (BABA) on infection of tomato plants by Meloidogyne javanica. Tomato seedlings were A, sprayed with 5, 10, 20, or $40 \mathrm{mM}$ BABA or B, soil-drenched with $2 \mathrm{ml}$ of 1.0, 2.5, or $5.0 \mathrm{mM}$ BABA. Seedlings were inoculated with $\approx 80$ second-stage juveniles (J2) per seedling 2 days after application. Plants were harvested 5 days after inoculation, and the number of $\mathrm{J} 2$ in roots and the root galling index (GI) were recorded. Values are means \pm standard deviations (indicated by vertical lines) of eight replicates. 
overnight). After polymerization of resin at $50^{\circ} \mathrm{C}, 2.5$ - $\mu \mathrm{m}$-thick sections were cut. For scanning electron microscopy, specimens dehydrated in the ethanol-dilution series were processed according to the method of Orion et al. (21). Samples were observed with a $\mathrm{T}-330 \mathrm{~A}$ scanning electron microscope (JEOL, Japan) at $10 \mathrm{kV}$.

\section{RESULTS}

Effect of chemicals on tomato and nematode infection. Tomato plants sprayed with $20 \mathrm{mM}$ AABA exhibited severe necrosis, mainly on lower leaves, and shoot fresh weights were significantly lower at harvest than those of control plants (Table 1). In contrast, leaves sprayed with BABA showed very few, slightly necrotic spots on lower leaves. Spraying plants with GABA did not cause phytotoxic symptoms on leaves. Soil-drenching with the three isomers did not have any phytotoxic effect on foliage. The younger leaves of plants sprayed with JA or MeJA were slightly chlorotic. Soil-drenching with BABA caused necrotic spots on roots, whereas AABA caused slight necrosis on root tips. Soildrenching with GABA did not cause phytotoxic symptoms on roots. Soil-drenching with JA or MeJA caused necrosis on root tips and slight chlorosis of leaves, whereas SA did not cause phytotoxic symptoms. Although the GI of plants sprayed with AABA or BABA were significantly lower than those of control plants 7 days after inoculation (Table 1), there were no significant differences in GI among treatments 30 days after inoculation (Table 1). There were fewer eggs on roots of plants sprayed or soil-drenched with BABA

TABLE 3. Development of Meloidogyne javanica in tomato plants sprayed with DL- $\beta$-amino- $n$-butyric acid (BABA) ${ }^{2}$

\begin{tabular}{lccrcc}
\hline & \multicolumn{2}{c}{ Females $(\%)$} & & \multicolumn{2}{c}{ Juveniles $(\%)$} \\
\cline { 2 - 3 } \cline { 5 - 6 } & Large & Small & & Stage 4 & Stages 2 and 3 \\
\hline Control & $75.6 \pm 5.1$ & $15.5 \pm 7.7$ & & $7.6 \pm 2.5$ & 0 \\
BABA & $13.3 \pm 4.1$ & $41.5 \pm 6.1$ & & $34.7 \pm 3.4$ & $10.3 \pm 1.7$ \\
\hline
\end{tabular}

${ }^{z}$ Tomato seedlings were inoculated with $\approx 300$ second-stage juveniles of $M$. javanica. Five days after inoculation, seedlings were removed from the soil, their roots were washed in water, and they were planted in uninfested soil. Seedlings were sprayed with $20 \mathrm{mM}$ BABA 1 day after planting. Three weeks later, nematode development was observed. Large and small females were $>250$ and $\leq 250 \mathrm{~mm}$ long, respectively. Values are means \pm standard deviations of five replicates.

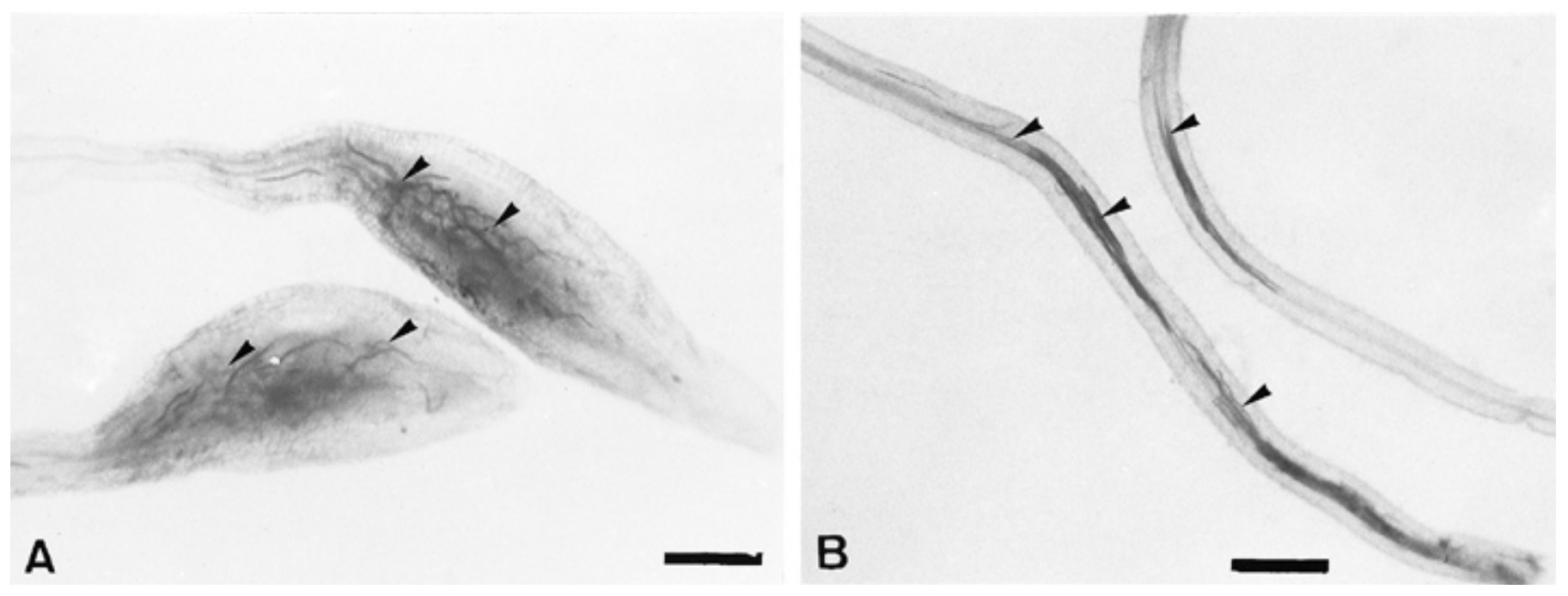

Fig. 2. Second-stage juveniles of Meloidogyne javanica in tomato roots. Roots were bleached with sodium hypochlorite, and nematodes (arrowheads) were stained with acid fuchsin 4 days after inoculation. A, Root of untreated plant. B, Root of plant sprayed with DL- $\beta$-amino- $n$-butyric acid 2 days before inoculation. Bars $=0.5 \mathrm{~mm}$.

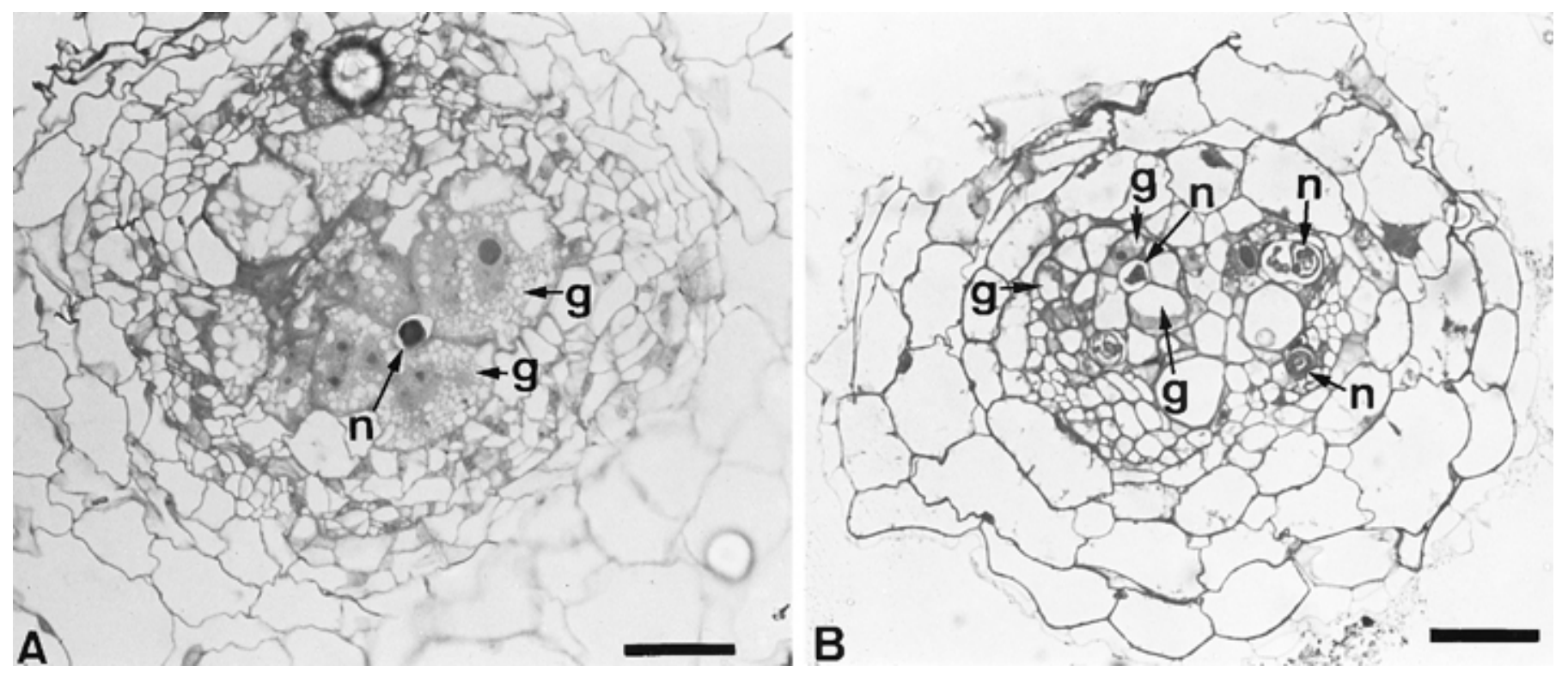

Fig. 3. Root sections of tomato plants 4 days after inoculation with second-stage juveniles of Meloidogyne javanica. A, Root of untreated plant. B, Root of plant sprayed with DL- $\beta$-amino- $n$-butyric acid 2 days before inoculation. $\mathrm{g}=$ giant cell; $\mathrm{n}=$ nematode. Bars $=50 \mu \mathrm{m}$. 
compared with control plants (Table 1). Juvenile immobilization in chemical solutions did not differ from that in water (data not shown).

Effect of BABA concentrations. Cotyledon defoliation was observed on plants sprayed with $40 \mathrm{mM}$ BABA. No phytotoxicity was observed at the other concentrations tested. Within the roots

TABLE 4. Effect of reiterative spraying or soil-drenching with DL- $\beta$-amino$n$-butyric acid (BABA) on infection of tomato plants by Meloidogyne javanica

\begin{tabular}{lcccc}
\hline Treatment & \multicolumn{1}{c}{$\begin{array}{c}\text { Shoot fr. wt. } \\
(\mathrm{g})\end{array}$} & $\begin{array}{c}\text { Root fr. wt. } \\
(\mathrm{g})\end{array}$ & $\begin{array}{c}\text { No. of eggs } \\
(\times 100)\end{array}$ & $\begin{array}{c}\text { Root galling } \\
\text { index }\end{array}$ \\
\hline Spray $\times 1$ & $5.4 \pm 1.3 \mathrm{ab}$ & $1.1 \pm 0.4 \mathrm{ab}$ & $81.9 \pm 30.0 \mathrm{~b}$ & $4.6 \pm 0.2 \mathrm{a}$ \\
Spray $\times 2$ & $5.8 \pm 1.6 \mathrm{ab}$ & $1.1 \pm 0.4 \mathrm{ab}$ & $63.5 \pm 24.6 \mathrm{bc}$ & $4.0 \pm 0.5 \mathrm{~b}$ \\
Spray $\times 3$ & $4.3 \pm 1.0 \mathrm{~b}$ & $0.8 \pm 0.2 \mathrm{~b}$ & $48.0 \pm 21.4 \mathrm{~b}-\mathrm{d}$ & $3.8 \pm 0.4 \mathrm{~b}$ \\
Drench $\times 1$ & $6.8 \pm 1.4 \mathrm{a}$ & $1.5 \pm 0.5 \mathrm{a}$ & $26.2 \pm 20.8 \mathrm{~cd}$ & $3.0 \pm 0.5 \mathrm{c}$ \\
Drench $\times 2$ & $6.6 \pm 1.9 \mathrm{a}$ & $1.4 \pm 0.5 \mathrm{a}$ & $34.3 \pm 11.5 \mathrm{~cd}$ & $3.4 \pm 0.6 \mathrm{bc}$ \\
Drench $\times 3$ & $6.6 \pm 1.4 \mathrm{a}$ & $1.5 \pm 0.4 \mathrm{a}$ & $17.1 \pm 8.8 \mathrm{~d}$ & $3.4 \pm 0.6 \mathrm{bc}$ \\
Control & $5.7 \pm 1.0 \mathrm{ab}$ & $1.3 \pm 0.3 \mathrm{ab}$ & $248.4 \pm 52.0 \mathrm{a}$ & $4.6 \pm 0.3 \mathrm{a}$ \\
\hline
\end{tabular}

$\mathrm{z}$ Tomato plants were sprayed or soil-drenched with 20 or $5 \mathrm{mM}$ BABA, respectively, at 10 -day intervals and inoculated with $\approx 400$ second-stage juveniles of $M$. javanica 2 days after the first application. Plants were harvested 40 days after inoculation. Values are means \pm standard deviations of seven replicates. Values followed by the same letter in a column do not differ significantly, according to the least significant difference test $(P=0.05)$. of plants sprayed with 10,20 , or $40 \mathrm{mM}$ BABA, fewer $\mathrm{J} 2$ were recorded than in untreated plants. GI of plants sprayed with 20 or $40 \mathrm{mM}$ BABA were lower than those of untreated plants (Fig. 1A). Reductions in the number of $\mathrm{J} 2$ in roots and in GI of plants soildrenched with 2.5 or $5 \mathrm{mM}$ BABA were recorded relative to the other treatments (Fig. 1B).

Pretreatment with BABA. The GI and number of $\mathrm{J} 2$ invading roots were reduced by pretreatment with BABA throughout the experimental period (Table 2). Large galls formed at the nematode infection sites on untreated seedlings (Fig. 2A), whereas plants inoculated 1 or 3 days after BABA spray had only a few, small galls. Moreover, in sprayed plants, most of the root-invading $\mathrm{J} 2$ were located in the vascular cylinder and failed to induce root galls (Fig. 2B). In plant roots inoculated immediately after spraying, J2 caused larger galls than those in plants inoculated 1 and 2 days after spraying. In plants inoculated 5 days after spraying, nematodes mainly invaded new lateral roots emerging from the shoot base, causing root galls. Giant cells induced in untreated roots were large and filled with cytoplasm (Fig. 3A), whereas those in BABA-sprayed plants were smaller and vacuolate (Fig. 3B).

Postinfection spray. Nematode development was delayed by a single spray with BABA after inoculation. In untreated plants, adult

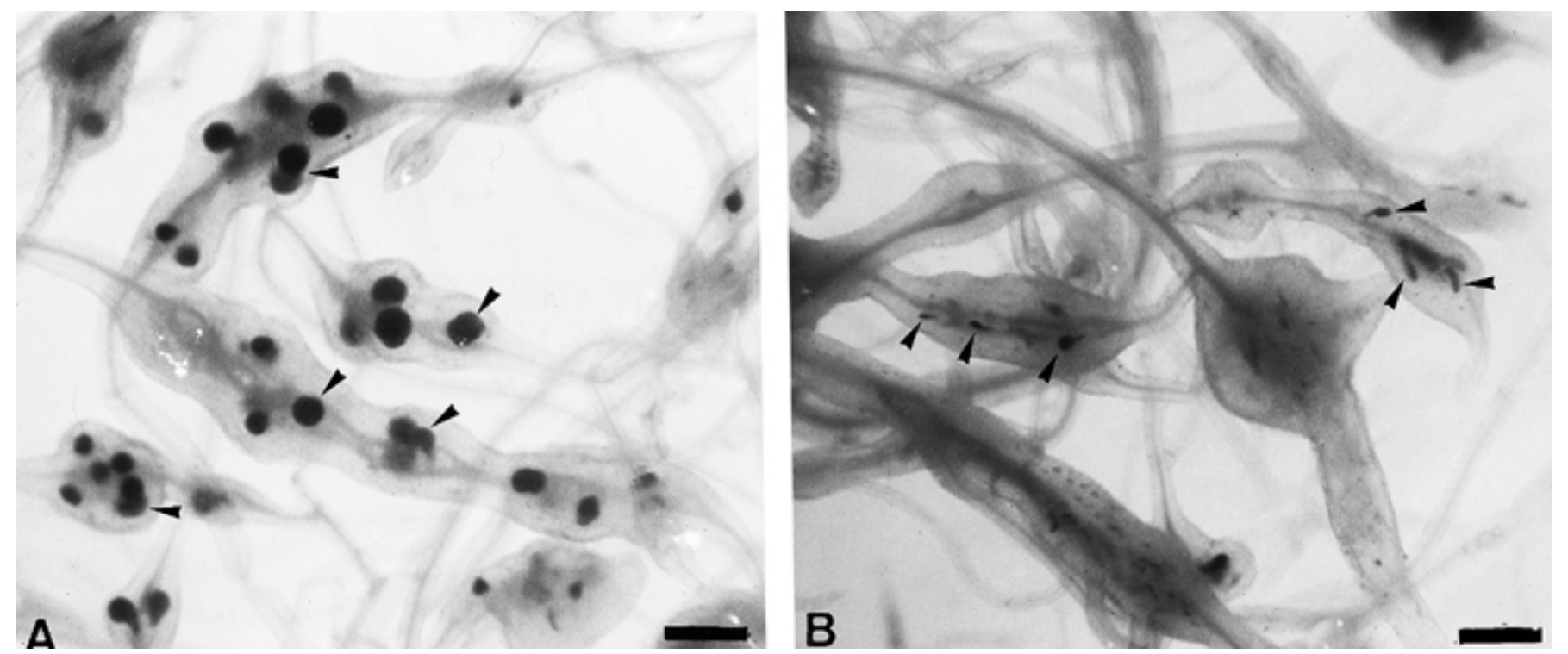

Fig. 4. Meloidogyne javanica in tomato roots. Roots were harvested 25 days after inoculation with second-stage juveniles, bleached with sodium hypochlorite, and nematodes (arrowheads) were stained with acid fuchsin. A, Root of untreated plant. B, Root of plant sprayed three times with DL- $\beta$-amino- $n$-butyric acid at 10-day intervals. Bars $=1 \mathrm{~mm}$.
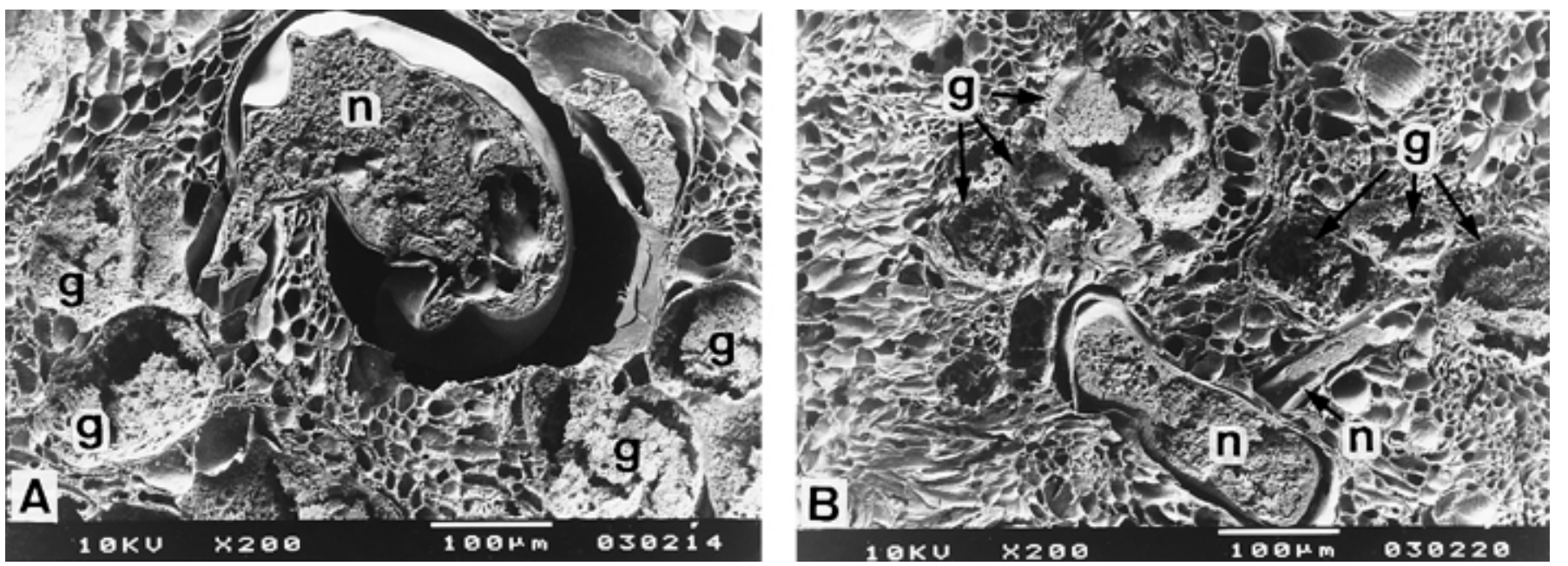

Fig. 5. Scanning electron micrographs of tomato roots infected with Meloidogyne javanica. Roots were harvested 25 days after inoculation with second-stage juveniles. A, Root of untreated plant. B, Root of plant sprayed three times with DL- $\beta$-amino- $n$-butyric acid at 10 -day intervals. $\mathrm{g}=$ giant cell; $\mathrm{n}=\mathrm{nematode}$. 
females larger than $250 \mu \mathrm{m}$ were predominant, whereas in roots of BABA-sprayed plants, small (up to $250 \mu \mathrm{m}$ ) adult females and fourth-stage juveniles were predominant (Table 3 ).

Reiterative application. Decreases in the number of eggs in BABA-treated roots as well as in the GI of plants soil-drenched with BABA were recorded after reiterative application (Table 4). There was no significant difference in shoot and root fresh weights among treatments. Retarded nematode development is shown in Figure 4. In BABA-treated roots, smaller females developed compared with control plant roots (Figs. 4 and 5). Giant cells in BABAtreated roots contained less cytoplasm than those of control roots (Fig. 5).

\section{DISCUSSION}

A variety of chemicals have been tested as plant-resistance inducers, and some have successfully induced local and systemic plant resistance to pathogens (14). In our study, several such chemicals were tested with $M$. javanica in tomato plants. Foliar spray with AABA or BABA reduced GI 7 days after inoculation; however, AABA caused severe necrosis on lower leaves. Roots drenched in MeJA had fewer root galls than control roots, but this seemed to be due to necrosis of root tips through which the nematodes penetrate, resulting in the latter not being able to induce feeding sites. The number of eggs in roots was significantly lower in plants sprayed or soil-drenched with BABA than in control roots, although no significant difference in root GIs was found 30 days after inoculation. Plants, therefore, were sprayed or drenched with BABA at $20 \mathrm{mM}$ or weaker concentrations in subsequent experiments.

SA, JA, and MeJA are considered plant defense signals and have induced resistance in several plant species (34). Induced resistance has been obtained in numerous plant species with SA, but the mechanism, including PR-protein induction and inhibition of catalase activity, has yet to be elucidated $(27,30)$. In contrast, exogenous JA or MeJA generally do not induce PR proteins (e.g., chitinases, glucanases, or PR-1); however, they have induced resistance to Phytophthora infestans in tomato and potato plants (6). Exogenous JA and MeJA induce expression of proteins involved in plant defense, including protease inhibitors, phenylalanine ammonia lyase, and lipoxygenase (29). In our experiments, foliar spray or soil-drenching with SA, JA, or MeJA was either phytotoxic to tomato plants or did not induce resistance to $M$. javanica. The mechanism governing plant resistance to plant-pathogenic nematodes may be somewhat different from the defense mechanism against fungal, bacterial, or viral pathogens.

None of the concentrations used in our study caused direct damage to $M$. javanica $\mathrm{J} 2$ in vitro. GABA is a strong inhibitory neurotransmitter in humans and other animals $(26,28)$ and appears to function similarly in nematodes (25). In our experiment, application of GABA by foliar spray or soil-drenching had no effect on nematode infection of tomato plants.

Root GI and number of $\mathbf{J} 2$ in roots of seedlings sprayed with $20 \mathrm{mM}$ BABA were lower during the early stages of infection, and giant cells induced in roots were smaller and vacuolate. Resistance phenomena in plants lasted at least 5 days after spraying. Soil-drenching with a lower concentration $(5 \mathrm{mM})$ of BABA also decreased root GI and number of $\mathrm{J} 2$ in roots. Postinfection spraying with BABA delayed nematode development, and most nematodes in the roots of plants sprayed or soil-drenched reiteratively with BABA failed to develop into large adults.

The exact mechanism of BABA-induced nematode resistance in tomato plants is not yet known. In view of our results, we speculate that treatment with BABA may render tomato roots temporarily less attractive to nematodes due to changes in plant metabolism or by making the plant cell wall physically harder for nematodes to penetrate. BABA is not metabolized in tomato plants; it is thought to bind to cell-wall proteins, resulting in cell walls that are resistant to fungal attack (5). The small, vacuolate giant cells in- duced by BABA treatment during the early period after spraying may be unable to supply enough nutrients to nematodes.

Another possible mechanism of resistance may result from synthesis in tomato roots of compounds with deleterious effects on nematode and giant cell development, because BABA applied to tomato leaves moves to the root system (5). A nematode may ingest BABA directly through the giant cells, which would then interfere with normal amino acid and protein synthesis by the nematode. Although $\mathrm{J} 2$ incubation in a BABA solution did not affect nematode mobility, the deleterious effect of BABA on nematodes cannot be ruled out, because ingestion of BABA by $\mathrm{J} 2$ in vitro through the stylet may be limited. It is interesting that BABA has been found in tomato root exudate (9), but the significance of this finding and its effect on nematodes are unknown.

In plant-fungus interactions, BABA effectively protected tomato plants from the fungus Phytophthora infestans, pepper plants from Phytophthora capsici, and tobacco plants from Peronospora tabacina $(4,7,13,31)$. However, the exact role of BABA in induced resistance in plants against fungal pathogens remains unclear.

In a previous work (22), several amino acids were used as antimetabolites for nematode control. Application of DL-aminobutyric acid to soil effectively reduced the number of galls induced by Nacobbus serendipiticus on tomato roots without harming the host plant, even though a much higher concentration of the amino acid $(150 \mathrm{mg} / 10 \mathrm{ml})$ was applied to the soil 2 weeks after inoculation with the nematode (22). A soil-drench with DL-methionine, which is not nematicidal, reduced the size of galls caused by $M$. incognita (32). DL-Methionine was believed to interact with root exudates, subsequently immobilizing the nematode. Soil-drench with DL- and L-proline reduced damage to bur marigold (Bidens tripartita) caused by Longidorus africanus (8). The exact mechanism of nematode control by these amino acids has not been clarified, but D-amino acids are believed to concentrate near root tips, the initial $N$. serendipiticus feeding site, thereby blocking essential metabolic pathways in either the plant or nematode and interfering with nematode nutrition (22).

Induced resistance to another root-knot nematode, $M$. hapla, was obtained in tomato and pyrethrum plants by prior inoculation with host-incompatible root-knot nematodes $M$. javanica and $M$. incognita (17). Moreover, resistance was systemically induced in the split-root system of tomato plants (18), suggesting that some signal is involved in resistance. However, the resistance mechanism in this system has not been clarified further.

We, therefore, concluded that BABA is the only chemical of those studied here that induces resistance to $M$. javanica in tomato plants by foliar spray or soil-drenching. Although induced resistance was temporary, reiterative BABA application retarded nematode development in roots. The mechanisms governing resistance to $M$. javanica in tomato and the effects of BABA on other nematode host plants and nematode species are under investigation.

\section{ACKNOWLEDGMENTS}

We thank M. Mor and A. Fisher for their technical assistance with light and scanning electron microscopy, respectively.

\section{LITERATURE CITED}

1. Byred, D. W., Kirkpatrick, Jr., T., and Barker, K. R. 1983. An improved technique for clearing and staining plant tissue for detection of nematodes. J. Nematol. 15:142-143.

2. Caruso, F., and Kuć, J. 1979. Induced resistance of cucumber to anthracnose and angular leaf spot by Pseudomonas lachrymans and Colletotrichum lagenarium. Physiol. Plant Pathol. 14:191-201.

3. Cohen, Y. 1994. Local and systemic control of Phytophthora infestans in tomato plants by DL-3-amino- $n$-butanoic acids. Phytopathology 84:55-59.

4. Cohen, Y. 1994. 3-Aminobutyric acid induces systemic resistance against Peronospore tabacina. Physiol. Mol. Plant Pathol. 44:273-288.

5. Cohen, Y., and Gisi, U. 1994. Systemic translocation of ${ }^{14}$ C-DL-3-aminobutyric acid in tomato plants in relation to induced resistance against 
Phytophthora infestans. Physiol. Mol. Plant Pathol. 45:441-456.

6. Cohen, Y., Gisi, U., and Niderman, T. 1993. Local and systemic protection against Phytophthora infestans induced in potato and tomato plants by jasmonic acid and jasmonic methyl ester. Phytopathology 83:1054-1062.

7. Cohen, Y., Niderman, T., Mösinger, E., and Fluhr, R. 1994. $\beta$-Aminobutyric acid induces the accumulation of pathogenesis-related proteins in tomato (Lycopersicon esculentum L.) plants and resistance to late blight infection caused by Phytophthora infestans. Plant Physiol. 104:59-66.

8. Epstein, E. 1972. Effect of pretreatment with some amino acids and amino acid antimetabolites on Longidorus africanus-infected and non-infected Bidens tripartita. Nematologica 18:555-562.

9. Gamliel, A., and Katan, J. 1992. Influence of seed and root exudates on fluorescent pseudomonads and fungi in solarized soil. Phytopathology 82:320-327.

10. Görlach, J., Volrath, S., Knauf-Beiter, G., Hengy, G., Oostendorp, M., Staub, T., Ward, E., Kessmann, H., and Ryals, J. 1996. Benzothiadiazole, a novel class of inducers of systemic acquired resistance, activates gene expression and disease resistance in wheat. Plant Cell 8:629-643.

11. Hammond-Kosack, K. E., Atkinson, H. J., and Bowles, D. J. 1989. Systemic accumulation of novel proteins in the apoplast of the leaves of potato plants following root invasion by the cyst-nematode Globodera rostochiensis. Physiol. Mol. Plant Pathol. 35:495-506.

12. Hussey, R. S., and Barker, K. R. 1973. A comparison of methods of collecting inocula of Meloidogyne spp., including a new technique. Plant Dis. Rep. 57:1025-1028.

13. Hwang, B. K., Sunwoo, J. Y., Kim, Y. J., and Kim, B. S. 1997. Accumulation of $\beta$-1,3-glucanase and chitinase isoforms, and salicylic acid in the DL- $\beta$-amino- $n$-butyric acid-induced resistance response of pepper stems to Phytophthora capsici. Physiol. Mol. Plant Pathol. 51:305-322.

14. Kessmann, H., Staub, T., Hofmann, C., Maetzke, T., Herzog, J., Ward, E., Uknes, S., and Ryals, J. 1994. Induction of systemic acquired disease resistance in plants by chemicals. Annu. Rev. Phytopathol. 32:439-459.

15. Malamy, J., Carr, J. P., Klessig, D. F., and Raskin, I. 1990. Salicylic acid: A likely endogenous signal in the resistance response of tobacco to viral infection. Science 250:1002-1004.

16. Malamy, J., and Klessig, D. F. 1992. Salicylic acid and plant disease resistance. Plant J. 2:643-654.

17. Ogallo, J. L., and McClure, M. A. 1995. Induced resistance to Meloidogyne hapla by other Meloidogyne species on tomato and pyrethrum plants. J. Nematol. 27:441-447.

18. Ogallo, J. L., and McClure, M. A. 1996. Systemic acquired resistance and susceptibility to root-knot nematode in tomato. Phytopathology 86 : 498-501.

19. Oka, Y., Chet, I., and Spiegel, Y. 1993. Control of root-knot nematode Meloidogyne javanica by Bacillus cereus. Biocontrol Sci. Technol. 3:115-126.
20. Oka, Y., Chet, I., and Spiegel, Y. 1997. Are pathogenesis-related proteins induced by Meloidogyne javanica or Heterodera avenae invasion? J. Nematol. 29:501-508.

21. Orion, D., Wergin, W. P., and Chitwood, D. J. 1995. Root cortical cell spherical bodies associated with an induced resistance reaction in monoxenic culture of Meloidogyne javanica. J. Nematol. 27:320-327.

22. Prasad, S. K., and Webster, J. M. 1967. The effect of amino acid antimetabolites on four nematode species and their host plants. Nematologica 13:318-323.

23. Rahimi, S., Perry, R. N., and Wright, D. J. 1993. Induction and detection of pathogenesis-related proteins in leaves and roots of potato plants infected with pathotypes of Globodera pallida. Fundam. Appl. Nematol. 16: 549-556.

24. Rahimi, S., Perry, R. N., and Wright, D. J. 1996. Identification of pathogenesis-related proteins induced in leaves of potato plants infected with potato cyst nematodes, Globodera species. Physiol. Mol. Plant Pathol. 49: 49-59.

25. Rand, J. B., and Nonet, M. L. 1997. Synaptic transmission. Pages 611-643 in: C. elegans, vol. 2. D. L. Riddle, T. Blumenthal, B. J. Meyer, and J. R. Priess, eds. Cold Spring Harbor Laboratory Press, Cold Spring Harbor, NY.

26. Rosenthal, G. A. 1982. Plant Nonprotein Amino and Imino Acids: Biological, Biochemical, and Toxicological Properties. Academic Press, London.

27. Ryals, J. A., Neuenschwander, U. H., Willits, M. G., Molina, A., Steiner, H.-Y., and Hunt, M. D. 1996. Systemic acquired resistance. Plant Cell 8: 1809-1819.

28. Satya Narayan, V., and Nair, P. M. 1990. Metabolism, enzymology and possible role of 4-aminobutyrate in higher plants. Phytochemistry 29:367375 .

29. Sembdner, G., and Parthier, B. 1993. The biochemistry and the physiological and molecular actions of jasmonates. Annu. Rev. Plant Physiol. Plant Mol. Biol. 44:569-589.

30. Sticher, L., Mauch-Mani, B., and Métraux, J. P. 1997. Systemic acquired resistance. Annu. Rev. Phytopathol. 35:235-270.

31. Sunwoo, J. Y., Lee, Y. K., and Hwang, B. K. 1996. Induced resistance against Phytophthora capsici in pepper plants in response to DL- $\beta$-amino- $n$ butyric acid. Eur. J. Plant Pathol. 102:663-670.

32. Tsai, B. Y., and Van Gundy, S. D. 1988. Effect of DL-methionine on host response to root knot nematodes. (Abstr.) J. Nematol. 20:661-662.

33. Vernooij, B., Friedrich, L., Ahl Goy, P., Staub, T., Kessmann, H., and Ryals, J. 1995. 2,6-Dichloroisonicotinic acid-induced resistance to pathogens without the accumulation of salicylic acid. Mol. Plant-Microbe Interact. 8:228-234.

34. Yang, Y., Shah, J., and Klessig, D. F. 1997. Signal perception and transduction in plant defense responses. Genes \& Dev. 11:1621-1639. 